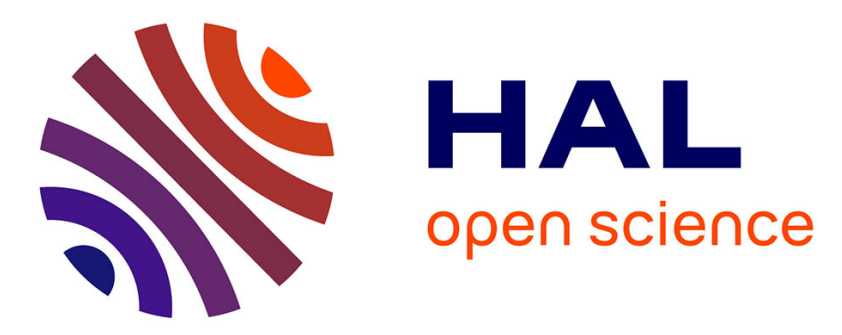

\title{
Factors influencing the transformation of new teaching approaches from a programme of professional development to the classroom
}

\author{
Rod Watson, Alex Manning
}

\section{- To cite this version:}

Rod Watson, Alex Manning. Factors influencing the transformation of new teaching approaches from a programme of professional development to the classroom. International Journal of Science Education, 2008, 30 (05), pp.689-709. 10.1080/09500690701854881 . hal-00513366

\author{
HAL Id: hal-00513366 \\ https://hal.science/hal-00513366
}

Submitted on 1 Sep 2010

HAL is a multi-disciplinary open access archive for the deposit and dissemination of scientific research documents, whether they are published or not. The documents may come from teaching and research institutions in France or abroad, or from public or private research centers.
L'archive ouverte pluridisciplinaire HAL, est destinée au dépôt et à la diffusion de documents scientifiques de niveau recherche, publiés ou non, émanant des établissements d'enseignement et de recherche français ou étrangers, des laboratoires publics ou privés. 


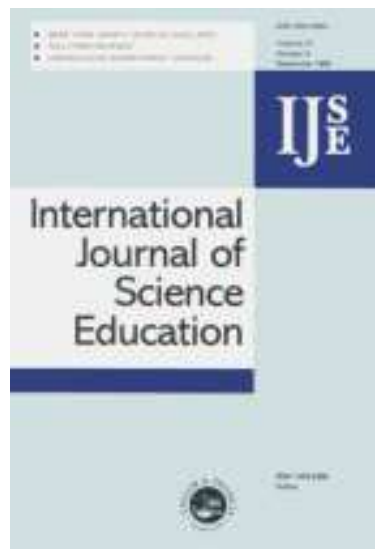

Factors influencing the transformation of new teaching approaches from a programme of professional development to the classroom

\begin{tabular}{|r|l|}
\hline Journal: & International Journal of Science Education \\
\hline Manuscript ID: & TSED-2007-0149.R1 \\
\hline Manuscript Type: & Special Issue Research Paper \\
\hline Keywords: & science education, teacher development \\
\hline Keywords (user): & \\
\hline
\end{tabular}

\section{s) ScholaroNE" \\ Manuscript Central}




\title{
Factors influencing the transformation of new teaching approaches
}

\section{from a programme of professional development to the classroom}

\begin{abstract}
A programme of professional development was designed consisting of 20 hours of workshops plus in-school activities. The implementation of new pedagogy was supported by teachers bringing examples of their work in the classroom to the workshops for discussion and reflection. The purpose of this study is to explore factors that influenced what teachers took from the professional development programme and how they used it in their own classrooms. It focuses on how the teachers' perceived needs were affected by the programme and how the implementation of new pedagogy was affected the level of in-school support. Data were collected to evaluate the expertise of the teachers early in the programme, their learning through the programme and factors that affected their learning. These data included tape-recordings of selected discussions during workshops, field notes of the workshops, classroom evidence collected by the teachers and portfolios constructed from it, and interviews with teachers after the programme had finished. The results indicate that success in learning from the programme was affected by two key factors: how teachers' perceptions of their needs interacted with the learning opportunities offered by the programme and how the level of in-school support affected the introduction of new pedagogy in the classroom. Unless both factors were positive learning from the professional development programme was variable.
\end{abstract}




\section{Background}

This study explores the factors that influence the development of expertise in the teaching of scientific inquiry in the UK. The research began with the design of a continuing professional development (CPD) programme for teaching scientific inquiry. The engagement of teachers in this programme and its impact on their knowledge, understanding and practice of inquiry was the focus of the research.

The design of the professional development programme was informed by the vast literature in the area (e.g. Hiebert, Gallimore and Stigler, 2002; Joyce and Showers, 1988; (Marx, Freeman, Krajick and Blumenfeld, 1998; Putnam \& Borko, 2000; Showers, Joyce and Bennett, 1987; Stein, Smith and Silver, 1999; van Driel, Beijaard and Verloop, 2001) that indicates effective programmes are those that:

- Engage teachers in collaborative long-term development related to their own teaching and their students' learning.

- Are related to the needs of the teachers in the contexts within which they work and take these contexts into account when developing new pedagogy.

- Provide teachers with support for the implementation of new pedagogy in their own schools.

- Focus on reflecting on how the new pedagogy can be applied effectively within the context of the specific content or curriculum teachers will be implementing. 
Such research emphasizes the importance of adapting teacher development programmes to the needs of individual teachers and recognising that teaching and learning in a classroom are influenced both by what goes on in the classroom and by factors outside the classroom. This socio-cultural perspective views science, science education, and research on science education as human social activities conducted within institutional frameworks (Lemke, 2001). Additional to these contextual frameworks, Hoban (p.29, 2002) states that 'educational change is a complex process involving many interconnected elements that have a dynamic effect on one another'.

A wide range of factors (Loucks-Horsley, Love, Stiles, Mundry and Hewson, 1998; Hoban, 2002, pp.35-36), both physical and social, influence what teachers take from a programme of professional development and how they use that in their own classrooms. Physical factors include class size, the size of rooms, resourcing of the school in terms of paper, books and scientific equipment. Social factors include the background of the learners, where they live, the expectations of parents (Hewson, Butler, Scantlebury and Davies, 2001; Hoban, 2002; Soudien and Colyn, 1992) and expectations of teachers (Hewson et al., 2001, Ladson-Billings, 1994). These factors impact on the teacher's pedagogic style, which is in turn influenced by the school's working environment (Fullan and Hargreaves, 1991, pp.5-6; Hoban, 2002; Wu, 1998) and expectations of the school management and Principal (Adey, 2004, pp104-5; Bredson and Johansson, 2000; Hoban, 2002; Sebatane, 1994). For example, Watson, Swain and McRobbie (1999) explored how teachers implemented scientific inquiry and showed that the way in which they did this was heavily influenced by the demands of external examinations and their use to 
judge the quality of schools. The school itself rests in a wider social setting as part of the local education authority, which has its own priorities (Hoban, 2002; Guariento, 1997) and these are heavily influenced by policies at a national level. Teachers bring to this setting their own particular biographies; experience both in and out of teaching and educational training (Fullan and Hargreaves, 1991). As a result of these factors interacting, teachers develop a range of teaching strategies adapted to the particular environments in which they teach.

The focus on the teaching of scientific inquiry draws on previous research (Watson, Wood-Robinson et al, 1999) where the nature of scientific inquiry has been interpreted as having the following features:

- students have to make their own decisions either individually or in groups: they are given some autonomy in how the scientific inquiry is carried out.

- scientific inquiry must involve students in using inquiry procedures such as planning, measuring, observing, analysing data and evaluating procedures. Not all scientific inquiries will allow students to use every kind of enquiry procedure, and scientific enquiries may vary in the amount of autonomy given to students at different stages of the investigative process.

Inquiry is thus seen as a process by which scientists use their procedural understanding to answer scientific questions. To teach inquiry effectively teachers need both knowledge and understanding of the domain of scientific inquiry (content knowledge) and how to use that knowledge and understanding to help students learn about the processes of 
inquiry (pedagogic content knowledge).

The content knowledge and understanding of scientific inquiry can be characterised in terms of the variety of scientific inquiries and the skills and procedures that are used within these inquiries. Various ways of categorising types of inquiry have been proposed (e.g. Lock, 1990; Gott and Murphy, 1987; Ruiz-Primo and Shavelson, 1995; Swain, 1991; Taylor; 1990; Watson, Wood-Robinson et al, 1999; Watson, Goldsworthy et al., 2002; Watson, 2006). Such a categorisation system allows teachers to design curricula that both reflect the variety of scientific inquiries used by scientists and match the learning needs of students (see for example of Harlen, 2000). In order to be able to deploy scientific skills and processes within different kinds of inquiry, procedural understanding is needed to be able to use the concepts of evidence associated with these skills and processes (Gott and Duggan, 1995; Millar, Lubben et al.,1994).

The pedagogical content knowledge and understanding for scientific inquiry is concerned with the specific techniques that can be used in the teaching of different aspects of scientific inquiry, and with the processes of interaction in the classroom. The notion that scientific inquiry is best taught through students learning by carrying out scientific inquiries is being increasingly challenged (Millar, Lubben et al.,1994; Watson and Wood-Robinson, 2002) and new teaching and learning strategies are being designed to teach specific aspects of inquiry explicitly (Foulds, Gott et al., 1997, 1998 and 1999, Goldsworthy, Watson et al., 1999, 2000; Sang and Wood-Robinson, 2002; Watson and Wood-Robinson,1998). The more focused teaching of different aspects allows clear 
educational objectives to be identified and opens the way to incorporate formative assessment strategies (Black and Wiliam, 1998a and b) in the context of enquiry (Watson, Wood-Robinson, et al., 2000). Teaching inquiry also involves managing the learning environment 'to foster a classroom culture in which students play active roles as science investigators in a mutually supportive learning community' (National Board for Professional Teaching Standards, 1998, p.29) in order to promote good quality discussion including evidence-based argumentation (Watson, Swain et al., 2004).

To design and implement the professional development programme and the research into teachers' engagement and learning, our study drew on this body of research to identify what could be termed 'expertise', or criteria for 'accomplishment', in the teaching of scientific inquiry. A provisional list of such criteria were used in developing a framework for professional development, which was extended once the development work began and teachers made their own contributions to our understanding of accomplishment:

1. understanding the various skills and processes involved in inquiry and progression in learning them;

2. understanding how the skills and processes are used in different kinds of inquiry;

3. using a range of strategies to help students learn specific skills and processes through both part inquiries and whole inquiries;

4. using a variety of different kinds of enquiry for teaching scientific inquiry; 
5. being able to communicate the criteria for judging successful learning of skills and processes to students and assist students in identifying what to do next to achieve the educational objectives within a particular inquiry context;

6. managing classroom discourse so that:

- there is a supportive learning environment in which learning is seen as a collaborative process;

- it is purposeful and planned with particular educational aims in view;

- it is constructive, with teachers and students building on each other's ideas;

- both the teacher and students justify their ideas.

The intention of the CPD programme was to help teachers develop their skills, and become accomplished in teaching scientific enquiry. During each phase of the CPD we reflected on the participants' engagement with the programme and their subsequent development towards accomplishment, by analysing data collected from of a variety of sources (see below). From this analysis we found that teachers progressed in different ways as they engaged in the programme, and that a range of factors were influential in determining the success of the CPD for each participant. Our main research question was:

What are the factors that influence successful transformation from CPD to the classroom in the teaching of scientific inquiry?

From previous research on teacher development cited above, we anticipated that teachers 
would have individual experiences and circumstances that would impact on the ways in which they responded to the professional development programme.

\section{The context of the study and design of the CPD}

The context for this study was a research and development project carried out at King's College London, UK and the Weizmann Institute, Israel in which we developed six CPD programmes designed to help teachers become more accomplished in different domains of science teaching. The purpose of the CPD programme in scientific inquiry was to help teachers move from a basic level of expertise to a level at which they considered themselves to be accomplished teachers of inquiry. The development of the CPD took place with different groups of teachers, each group experiencing a trial run of the programme and contributing to its further development. The final format of the programme was reduced from five whole day workshops, spread over several months, to four. All the teachers were volunteers who responded to information communicated through King's College partnership schools.

\footnotetext{
The CPD programme was planned with three key ideas in mind. First, it should challenge teachers to develop their own practice by thinking about teaching scientific inquiry in ways that were new to them, second, it must take into account differing needs of different teachers and, third, teachers' learning must be applicable in their own school contexts (Stein, Smith and Silver, 1999). The final CPD programme consisted of about 20 hours of workshops at college, plus additional tasks, which teachers carried out in their
} 
own classrooms. Each workshop was divided equally between two kinds of activity: 'expert input' and 'practice-based discussions'. The expert inputs were designed to present new ideas to teachers and to demonstrate innovative pedagogy for teaching specific aspects of procedural understanding to students in schools. Teachers were then encouraged to carry out a variety of tasks in their own schools. The tasks were designed to help teachers gain experience in using new pedagogy in their school contexts and to demonstrate their progression towards accomplishing skills in different aspects of inquiry. These experiences resulted in artefacts such as videotapes, materials written by teachers and students. The discussions that took place in the workshops were based on these artefacts and were designed to help teachers share their reflections and explain their evidence of accomplishment. Artefacts and written reflections were collated into individual professional development portfolios.

In order to take into account teachers' needs the CPD programme was planned so that there were many opportunities to elicit teachers' perceptions of their needs. At the beginning of the first workshop participants completed a questionnaire in which they were asked to estimate the competence of pupils in one of their classes with respect to twenty-seven skills and procedures. We were conscious of the need to build a community of practice amongst the teachers in order to encourage them to share experiences about school and so avoided asking them directly about their own teaching. By identifying skills and procedures where their pupils were weak, we were able to highlight skills and procedures that could be targeted more effectively. Workshops were planned in advance, however, the detailed contents of each workshop were kept flexible 
to address the needs of teachers. Analysing the results of the questionnaire was the first method of identifying needs and helped the professional development providers select from a range of possible activities to be used.

Further activities in the initial part of CPD programme included discussions of the meaning of accomplishment and a consideration of what evidence might be used to demonstrate accomplishment drawing on existing video material. When teachers were meeting for the first time we did not want them to feel threatened by exposing their own practice to each other. Our main aim was to assess the starting points of individual teachers and how they responded to ways of teaching inquiry with which they were not familiar. Teachers were introduced to a range of teaching approaches selected from the AKSIS materials (Goldsworthy, Watson and Wood-Robinson, 1999, 2000) and encouraged to select one for implementation in their own classrooms and to video-record themselves. The teachers were encouraged both in the workshop sessions and in less formal settings (e.g. over coffee) to discuss the teaching approaches they had chosen.

Subsequent meetings in the programme involved teachers sharing examples of their own work in response to the tasks they chose in first workshop. Our aim was to help teachers challenge their own perceptions about teaching inquiry. Viewing their video-tapes formed the basis of reflective analysis and rubrics were introduced for evaluating the quality of discussion in inquiry lessons. Evaluation focussed on:

- whether classroom discussion was constructive

- how pupils built on one another's ideas 
- whether a supportive environment was created

- whether pupils were encouraged to be reflective by describing and explaining their thinking

- the openness of the inquiry as shown by the extent to which decisions in the inquiry process were made by the teacher or the pupils.

By reviewing evidence from their classrooms over the four workshops teachers were able to construct a portfolio. The final meeting of the programme involved teachers sharing their portfolios, explaining the activities that they had used and how these illustrated their personal development. Discussion amongst the group focussed on reflecting on how the portfolio showed evidence of achievement of the various accomplishments listed earlier in this paper.

\section{Research design and data sources}

The aim of our research study was to investigate how the factors influencing successful transformation interact for different teachers in different school settings and contexts. We particularly focussed on how the needs of the teachers were addressed within the CPD programme and how teachers' interactions with colleagues in school affected the implementation of their new pedagogy. Ten teachers attended the workshops through consecutive Phases of the CPD trials.

In order to address our research question we used a variety of data sources including:

- field notes of meetings and audio/video recordings of discussions held during the 
professional development meetings;

- portfolio materials: written and video materials that teachers collected to demonstrate their progression in teaching inquiry;

- interviews: individual interviews of teachers;

- school visits.

The data were collected throughout the implementation of the CPD programme, and the processes of data collection and analysis were iterative. Each phase of data collection and analysis informed subsequent data collection. The methodological approach was qualitative, and involved a combination of action research, survey and case study approaches (Denscombe, 2002). The action research aspect is characterised by the influence of analysis on subsequent CPD design and related data collection, the survey approach by questionnaire data and interview protocols, and the case study approach through the thematic analysis of each teacher's engagement and response to the CPD. The research outcomes take the form of descriptive narrative accounts, and are the product of data reduction, by two researchers, based on the criteria for developing accomplished teaching of scientific inquiry.

Biographic details gleaned from teacher interviews and teachers' discussions in the workshops and informal settings provided a starting point for building descriptions of the teachers and their progression in learning to teach inquiry. Details included how long they had been teaching, whether they had any post of special responsibility for science in the school and their reasons for attending the professional development programme. 
These included their perspectives and practices about the use of inquiry in their classrooms; the extent of their participation in the professional development programme; their school circumstances and, in particular, how professional development was viewed, supported and shared by the school and the science department. Finally, we explored how teachers perceived their practices changed as a result of the programme of professional development.

Teachers' portfolios provided an insight into programme implementation in their classroom. Materials included written or video taped pieces of evidence arising from tasks that were completed in school, such as lesson plans, lesson observation, selfevaluation and pupils work. Six of the ten teachers completed portfolios by the end of the CPD programme. Within the portfolio, the materials were analysed by the teachers and were cross referenced using criteria for accomplishment. Teachers selected evidence they felt showed their progression in relation to each accomplishment. These materials also formed the basis of extended teacher discussions about the nature of evidence that would demonstrate accomplishment. The discussions were recorded forming part of the workshop records.

\footnotetext{
The end-of-programme-interviews were tape-recorded, transcribed in full and analysed for key themes by two researchers. Themes included: how teachers thought the professional development programme had affected them, their previous experience and their roles within the school, their reactions to and participation in the professional development programme and the support mechanisms in the school. The interviews
} 
allowed us to clarify ideas that had developed from the other data sources, and look more closely at individual teachers rather than the whole group. We were interested in how teachers developed away from the group.

Information about school support and culture was recorded in field notes associated with the workshops and during school visits. We drew on events such as non-attendance to sessions due to requests from senior management, teachers sharing ideas with their department and a wider awareness of the project when we visited schools. We collected information about the cohesive ways of supporting staff within the science department, how senior management viewed professional development, characteristics of the students and the socio-economic setting of the school.

\section{Analysis and results}

These different sources of data were combined to produce a profile of each teacher and how he or she responded to the professional development programme. Thematic categories of information were tabulated so that both researchers could build profiles of the teachers by collating and cross-referencing inferences from all these data sources. The categories included reason for participation, support in school, time issues, initial view of teachers own practise and/or view of pupil ability, awareness of change in practice, evidence of change and view of the portfolio. The conceptual framework for this thematic analysis was based upon our definition of accomplished practice, and identification of themes from the data sources that impacted on that accomplishment. The final table of 
profiles shows contextual factors and summaries of professional learning for the ten teachers (Table 1). Cross-referencing of inferences from the data sources was undertaken by both researchers to confirm profiles for each teacher. The data sources were revisited several times during the construction of profiles in order to clarify emergent themes and check that all the information had been thoroughly processed.

[Insert Table 1 here]

Looking at the ten teachers described in Table 1 it can be seen that although the contents of the workshops were common for all participants, what they learnt varied considerably. There was some commonality with many teachers reporting improved ability to reflect and look critically at own practice, use of an increased the range of strategies to help students learn specific skills and processes and awareness of a greater range of scientific inquiries. Some outcomes were, however, not so directly related to the core aims of the professional development programme as encapsulated in the listed 'accomplishments' and were more specifically related to the needs of individual teachers such as:

Helen: Ideas about how to improve professional development in my own science department.

The varied response of the participants to the professional development programme raises the question of what it is about the particular participants and the circumstances in which they work that has caused such a varied response. The ten teachers in our study were drawn from a wide variety of schools, had a variety of different roles in their schools and a wide range of levels of experience as science teachers. Amongst this small number of teachers we could not detect any systematic effect of any of these factors on what teacher 
learnt from the professional development programme. However, two factors that seem to have been crucial in influencing teachers' responses are:

- how the course interacted with their perceived needs;

- the interactions between the teachers and their school circumstances.

\section{$\underline{\text { Addressing teachers' needs }}$}

The reasons for teachers being on the professional development programme appear to have been critical in how they responded to the programme. Some teachers were there primarily to improve themselves (e.g. Helen, Charles and Liz). In discussions they tended to focus on what a teacher should be able to know and do to be an accomplished teacher, whereas other teachers (Mila and Milton) were less focussed on their own learning and tended to discuss their pupils rather than themselves as teachers.

For example when Helen was asked what she had learnt from the programme she said:

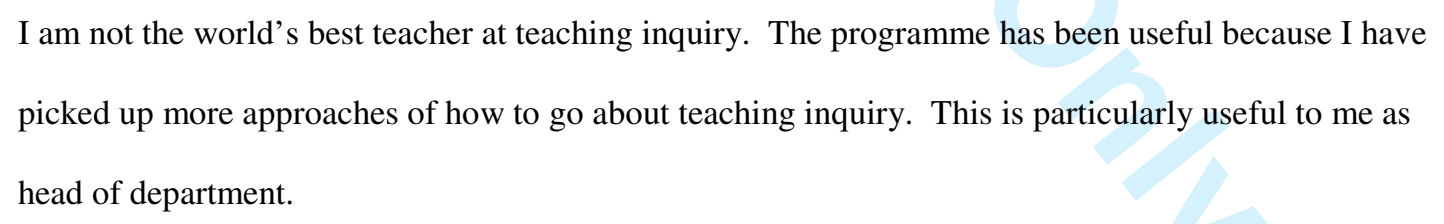

In contrast Mila, in answer to the same question, did not think she had gained much knowledge but thought her pupils would be able carry out better evaluations: 


\begin{abstract}
...my knowledge is pretty much the same. I understand what they're all about and so on, and what they're trying to achieve, but what CPD has done is clarify the components - and the sub-components more importantly - and the result of that is how to break it up and focus on particular bits in order to develop their evaluation of plans and their evaluation of data.
\end{abstract}

Teachers who were focussed on their own learning tended to adopt a more reflective approach. This led to a deeper level of engagement with the programme. These teachers reflected on their needs as teachers of inquiry and used what the professional development programme had to offer. When trying out tasks set in the workshops in their own schools they tended to adapt the tasks to make them fit in with what they were doing already. For example, after workshop 2 teachers were asked to try out in their own classrooms one of the new inquiries introduced in the workshop. Charles took the inquiry 'Mystery powders' and reworked the inquiry so that it fitted in with some work he was already doing with his year 9 class on classifying chemicals. Similarly Liz took activities designed to teach specific aspects of inquiry and integrated these with whole inquiries that she was already carrying out. None of the teachers who were less focussed on their own learning (e.g. Mila and Milton) went through this process of adaptation and transformation of the tasks. When tasks were done they were seen as add-ons to the normal practice. For example, Mila used the 'Mystery powders' inquiry but this was not integrated with the normal scheme of work. The professional development was seen more as a set of 'tips for teachers' or activities that could be added on to what was already happening.

Teachers were agreed that one aspect of the professional development programme that 
affected their perceptions of their needs was the 'expert input'. For teachers who came to the professional development programme with a desire to improve their practice in teaching inquiry, the expert input showed them how this could be done. It lifted them out of their normal routines and showed them how things could be different:

\begin{abstract}
Fahima: I didn't really have a clear idea about enquiry... if there wasn't, you know someone, to kind of guide you along the way, you could get very kind of caught up in everything that you already do.
\end{abstract}

Liz: I definitely think an expert input was necessary because it just gave us new ideas...

\begin{abstract}
Mila: I think that helps, because otherwise I would have been... a bit lost, not quite sure what I was meant to be doing... Learning what other people are doing is useful, but I think your input... was probably more important.
\end{abstract}

Similar by Peers, Diezmann and Walters (2003) reported that materials provided by the professional development provider showed 'an alternative vision of science education'.

The quotations from the teachers above show that the 'needs' of the teachers were not clearly defined. Whatever their starting points, the stimulus provided by the 'expert' was helpful in clarify directions in which they could develop and they welcomed this clarity of direction. The first workshop was important in this respect in that one aim was to try to paint a picture of what an expert teacher of inquiry should look like. Teachers were asked to write down the characteristics of an expert teacher of scientific inquiry, to discuss what they had written with one another and finally to compare their own characteristics with a list which we had generated. Analysis of the written documents 
and the tape-recorded discussions showed that this part of the workshop was useful in establishing the learning aims for the programme of professional development. The teachers' own analyses of what was meant by accomplished teaching of scientific inquiry tended to be constrained by the particular circumstances in which they were working, so for example, at the beginning of the professional development programme only one of the ten teachers thought that teachers should be able to teach using a variety of different kinds of inquiry, although when this idea was introduced to them, teachers readily accepted the range of inquiries currently used by them was very limited. Similarly, only two teachers mentioned being explicit about learning objectives (accomplishment 5) and only half of them mentioned that teachers needed to have a range of teaching strategies to teach specific aspects of inquiry. Again, when these ideas were introduced to teachers, they readily accepted them as valuable goals and worth working towards. The teachers' perceptions of their needs were thus modified by the professional development programme itself.

As well as setting the direction for the learning, the expert was also seen as important in helping to acquire a deeper understanding of new pedagogic approaches: to help teachers to go beyond knowing what to do in the classroom to understand why a particular approach is being used:

\footnotetext{
Charles: Some of the exercises were quite refined and the expert was able to explain ways of using the material...particularly what point we were trying to get to with the material. Whereas if I'd just been handed the material, I'd have said: 'Oh yeah, this is pretty interesting', and I could have used it in a completely different way to what was intended...
}

URL: http://mc.manuscriptcentral.com/19/sed Email: editor_ijse@hotmail.co.uk 


\begin{abstract}
Int: So, the actually showing of the materials and showing how they might be used?
Charles: Yes, but also explaining the teaching point, or what understanding or skill that the material is trying to get at.
\end{abstract}

The expert was also seen as important for challenging teachers: by probing understandings and reacting to individual needs:

\begin{abstract}
Helen: I think, if you have got a couple of teachers who can talk, you could have a lot of ideas, but I think where the expert, where you, come in, is: you have seen a lot a teachers and you know what they can do and you know the questions to ask. Like when you were doing it with John and doing it with me, you knew what questions to ask and pushed me a bit further.
\end{abstract}

The role of the 'expert' helping to support the development of individuals could be seen in the first two workshops in discussion of the quality of teaching in videos. In the first workshop teacher viewed a ten-minute clip of a lesson showing an accomplished teacher of inquiry. They were then asked to discuss the quality of the talk in the classroom (accomplishment 6) and to identify the criteria by which they judged quality. The first reaction of the teachers was to make mainly negative judgments about the teaching and to suggest how it could have been done better. Teachers were not good at identifying the criteria used to make the judgments and this was particularly true of Mila and Milton, from our six exemplar teachers. After framing the discussion to consider the criteria for judging the quality of dialogue in the classroom, the expert introduced three rubrics designed to evaluate different aspects of the dialogue and teachers used these to evaluate the quality of the dialogue whilst watching the video again. The activity of watching videos was repeated in workshop 2, but this time using videos that teachers had made in 
response to the task set in workshop 1. This time the discussion was more focussed and was based on the rubrics provided in workshop 1. Teachers' comments on one another's videos tended to be less judgmental and more descriptive, identify which criteria for good discussion were being met and which not. This left teachers with a clear picture of what needed doing to improve the quality of inquiry dialogue in their own classrooms.

Whereas the expert input was seen by all the teachers has helping to clarify their needs, the 'school-based discussions' were seen as important in providing the concrete support that they needed in order to apply their learning from the workshops in their own schools. The school-based discussions were another aspect of the programme that made it adaptable to teachers' needs by exploring how new pedagogic practices might be adapted to their own classrooms. The discussions provided teachers with ideas for approaching the teaching of different aspects of inquiry along with practical advice on how to manage them in the classroom.

Fahima: I think it's really good when you talk to other teachers. It's just about sharing ideas... seeing how other people do enquiry in their own schools and then using that information to kind of feed back into your own work. For example, if someone recommended a particular activity and said: 'Oh yeah, I did this activity and it was really good', then I would come back to school and try that because I would think: 'Oh yeah, OK you know, they thought it was really good so I'm going to try that and see how it works for me'.

Charles: That is very useful, because you're sharing ideas, sharing experiences, discussing ways of doing things, going over problems people have had: picking up a very useful technique for doing something. So I found discussing with the other teachers beneficial. 
Interactions between the teachers and their school circumstances

\begin{abstract}
An obvious factor that was related to teacher learning in the professional development programme was the level of involvement in the programme. Of the six exemplar teachers' above four (Helen, Charles, Fahima and Liz) attended all or all but one of the workshops and all except Liz completed a portfolio of evidence and reflection. In contrast Mila attended three out of five and Milton two out of five sessions and neither of them completed a portfolio.
\end{abstract}

The quality of support and interaction between the teacher and the school, the science department and science colleagues was important in determining the effectiveness of the professional development programme. Teachers who came from schools where there was strong support for teachers in their professional development were on the whole more successful than those who came from schools where support mechanism were weak or non-existent. Three aspects of the interaction between the school and the professional development programme were important.

\footnotetext{
Firstly, it was necessary to obtain the support of senior management in schools to allow teachers to attend the professional development programme during school time, but having obtained this support, schools were varied in their commitment to the professional development programme and at some schools other priorities were allowed to over-ride the commitment to the professional development programme preventing teachers from
} 
attending all the sessions.

In three of the schools events occurred that were deemed to be more important than the professional development programme and prevented the teachers from attending. These events included both unanticipated events and anticipated events such as examinations. At Mila's school an incident with pupil behaviour arose and this resulted in Mila missing one of the professional development workshops:

Int: Do you think people in your school made it easier, or hindered you in participating in the programme and making changes to your teaching?

Mila: They haven't made it easier, but we can do what we want. Everyone knows that I'm doing this... and nobody's saying no...

This ambivalent attitude from the school was not just one-sided, but was also held by Mila herself. When discussing what happened in school as a result of the incident Mila said:

Mila: Andrew was saying: 'go', and I said: ‘no, I can’t go because I should be going'. But... I knew that... there would be reports and things to write. And then, it was quite major. The head was the one who was making it out to be major, but Lillie got hit, and Mat got hit, and I got pushed around, like seriously pushed around.

The low level of school support was probably a factor in the weak participation of Milton in the professional development programme. It was obvious from the outset that senior 
management had doubts about releasing him from the school to attend the programme and that mechanisms for sharing amongst the staff in the science department were weak. Milton had no experience of teaching inquiry and so in the absence of school support it is perhaps not surprising that he dropped out after the first two workshops.

The second aspect of school support that was found to be necessary was whether there were formal or informal mechanisms to enable teachers to feedback what they had learnt from the professional development and to discuss with science colleagues. Liz's school went as far as facilitating her to attend the programme but beyond that there was no inschool support and there was no opportunity to discuss what she was learning with science colleagues. In contrast in schools of Helen, Charles and Fahima there were effective informal or formal mechanism for discussing the learning from the professional development programme with other members of staff. For example talking about his school Charles said:

\begin{abstract}
They've all been very supportive. When I've been away for the day, colleagues from my department will provide cover... My head of department is very happy for me to teach in whatever way I feel fit, within the constraints of obviously making sure my classes are covered the material they need to have come across, and however I get there, he doesn't really mind. And if I haven't quite covered a few bits of it, he's not that stressed about it...
\end{abstract}

Int: Would he see what you're learning of any benefit to him, or is that expecting too much?

Charles: Possibly. I mean, he's been teaching for fourteen, fifteen years and yes, he has seen some of it as beneficial, although to completely change what he does I don't think is very likely. Although 
particular exercises I've developed, a mini-investigation I've put together, he may take that and put that into his teaching.

The third aspect of school support was support for implementation in the classroom. Again in the schools of Helen, Charles and Fahima there was support for changing classroom practice:

\begin{abstract}
Fahima: Within my department I think they were just really keen, and actually the head of the school as well was really keen for me to go. My head of department was very interested in what was happening... What encouraged me was talking to the head of physics... and being able to say: 'OK, you know, I'd like us to incorporate some more scientific enquiry. This is my idea. Where do we go from here? How can we put it in?' and stuff like that. And that was really helpful...
\end{abstract}

\begin{abstract}
In contrast Munby, Cunningham and Lock (2000) describe the negative effects on professional development when members of the science department feel that there is insufficient space in the curriculum to experiment with new approaches.
\end{abstract}

\begin{abstract}
Another aspect of the development of new practice in the classroom was in carrying out the tasks needed to develop the portfolio:
\end{abstract}

\begin{abstract}
Int: Some people have been unable to complete the portfolio by the end of the course. What are the factors that encouraged or discouraged you from getting the portfolio completed?
\end{abstract}

Helen: For me, I was encouraged to complete it because I found it useful for reflecting on what I am doing in class when teaching enquiry.

URL: http://mc.manuscriptcentral.com/25sed Email: editor_ijse@hotmail.co.uk 
However, the portfolio did take time: both planning time and time in the classroom.

Int: Right, OK. Are there any other factors that have affected getting the portfolio completed or not?

Charles: Yes. Working within an existing scheme of work, which I have to follow and also the time constraints, because it's obviously quite easy to teach things...the way you did last year. It doesn't require much thought or time or planning. But if you want to then say: 'well, I'm going to teach this in a different way', it often means re-planning large parts of the course.

This time requirement was in competition with many other demands in the schools. Ones mentioned by teachers were administrative duties such as organising teachers to cover absent colleagues, an Ofsted inspection, examination demands, marking coursework and one teacher whose busiest time of the year coincided with the professional development programme and lasted from September to February! Whether the professional development programme or the school time demands was given precedence was strongly related to the level of school and departmental support.

\section{Discussion}

Two factors appear to have been particularly influential in determining how much individual teachers learnt from this professional development programme. The first was the extent to which teachers perceived the programme as addressing their needs as teachers and how teachers were able to interact with the programme to take what it had to offer themselves as teachers. The second factor was the level of support from the school and how the teacher was able to interact with colleagues and make changes in the 
classroom. These factors have been carefully extracted from the range of data sources, though other factors may have been influential in teachers' responses. There may have been limitations in the ways in which individual teachers' needs were reported, or in the information they provided about their experience and situations. The results are dependent on teachers' accounts of themselves and their beliefs.

Significant learning was made by all the teachers who saw the professional development programme both as an opportunity for teacher change and who worked in schools where there was strong support (e.g. Helen, Fahima and Charles). For teachers where neither of these conditions existed, there was little learning (e.g. Milton). If the teacher saw the professional development programme as an opportunity for teacher change but worked in schools where support was weak, success of the professional development programme was less certain (e.g. Liz), and finally if the teacher did not see the professional development programme as an opportunity for teacher change but nevertheless has some school support success was also less certain (e.g. Mila).

Similar factors were identified by Adey (2004, p.97): the 'teachers' stance' towards the professional development and the 'school ethos'. In the detailed case-study of three teachers, two had a positive stance and worked in supportive environments, resulting in substantial development of their pedagogy. The third teacher had a positive stance but worked in an environment where support was weak and this impeded her professional development. 
If transformation of teachers' practice is envisaged then there also needs to be an interaction between what is being learnt in the professional development programme and the context in which teachers work. In the current study the mechanisms incorporated into the professional development programme to identify and address individual teachers needs were on the whole successful, but what was less successful were the procedures for supporting teachers in their schools. There was a strong emphasis on supporting teachers in schools through the development and discussion of the portfolio, but this was not sufficient to compensate for weak or non-existence in school support from science colleague and senior management.

Rather than adopting a new curriculum or pedagogic strategy, teachers often adapt the strategy in response to an interaction between the new curriculum or pedagogic strategy and the situation in which they work (Scholtz, Watson and Amosun, 2004). An evolutionary perspective helps to interpret why teachers responded in different ways to a curriculum innovation designed to change their pedagogic practice (Johnson, Monk \& Hodges, 2000; Monk, Johnson, Swain, 1998). Such a perspective assumes that the range of pedagogic strategies that teachers use in their classrooms is selectively retained because they survive in particular classroom conditions:

Teachers are not generally irrational opponents of change but they rationally weigh alternatives according to the realities they perceive (Crossley \& Guthrie, 1987).

The conditions that have been identified as necessary in the particular programme of teacher development that has been described in this paper are related to the level of inschool support. Huberman and Miles (1984) identified the quality and quantity of assistance that users of an innovation received once change was in process as being the 
most significant factor in determining the success, or not, of an innovation. Similarly Placier and Hamilton (1994) identified several conditions that need to be in place to support teacher learning. These conditions were present for the most successful of the six exemplar teachers described. The conditions are a positive working environment such as flexibility and willingness to experiment and so allowing teachers autonomy to change their practice. There should also be collegiality amongst staff and willingness to change.

The limited success of our professional development programme in bringing about change in all the teachers indicates that further consideration needs to be given to how support for introducing new pedagogy into the classroom can be strengthened. A possible way forward is indicated in the study by Dillon, Duschl et al. (2002). They described a professional development programme with many features that were similar to the programme discussed in this paper. In the programme of Dillon, Duschl et al. (2002) teachers identified and carried out a piece of research about science pedagogy in their own schools. An additional feature of their programme, that could have enriched the programme discussed in this paper, was a partnership between the higher education institution and the local education authority. Within the programme science advisors from the local education authority were involved in identifying local priorities and interests for professional development, identifying teachers and schools to be involved in the programme and ensuring that the school was were committed to supporting teachers in carrying out their research in school. At least two staff members were always present at the workshops run in this programme and a special role of the local science advisors was to support the teachers in their in school work, including their negotiations with their 
managers. Without such close ties between the providers of professional development and the schools in which teachers work, our study indicates that at best successful change in pedagogy will be rather hit and miss and that if teachers are not well motivated to change success is unlikely.

Not all professional development programmes are of the kind described here (Stein, Smith and Silver,1999). Many professional development programmes do not attempt to change transform practice but simply provide information to bring teachers up to date with such things changes in the syllabus or the details of summative assessment practices. Professional development programmes with limited aims such as these do not require extended time-scales to change teachers or in-school support. If, however, the aim is to transform teachers' classroom practices, it is important to consider how this can be supported within the school.

\section{References}

Adey, P. with Hewiitt,,G., Hewitt, J. and Landau, N. (2004) The Professional Development of Teachers: Practice and Theory. London, Kluwer Academic Publishers.

Black, P.J. and Wiliam, D. (1998a) Inside the Black Box: Raising Standards through Classroom Assessment. London, King's College London.

Black, P.J. and Wiliam, D. (1998b) Assessment and Classroom Learning. Assessment in 
Education 5(1) 7-74.

Bredson, P.V., \& Johansson, O. (2000). The School Principal's Role in Teacher

Professional Development. Journal of In-service Education, 26, 385-401.

Crossley, M., \& Guthrie, G. (1987) INSET and the Impact of Examinations on Classroom Practice. Teaching and Teacher Education, 3, 65-76.

Denscombe, M. (2002) The Good Research Guide. Buckingham: Open University Press.

Dillon, J.S., Duschl, R., Sissling, S., Watson, R. (2002) Science teachers as researchers a model for professional development School Science Review 84 (307), 43-48.

Foulds, K. Gott, R. and Duggan, S. (1997) Science Investigations 1, Collins.

Foulds, K. Gott, R. and Duggan, S. (1998) Science Investigations 2, Collins.

Foulds, K. Gott, R. and Duggan, S. (1999) Science Investigations 3, Collins.

Goldsworthy, A., Watson, J. R. and Wood-Robinson, V. (1999) Investigations: Getting to Grips with Graphs. Hatfield, Association for Science Education.

Goldsworthy, A., Watson, J. R. and Wood-Robinson, V. (2000) Investigations: Developing Understanding. Hatfield, Association for Science Education.

Gott, R. and Murphy, P. (1987) Assessing Investigations at Ages 13 and 15, Science Report for Teachers 9. London, DES.

Gott. R. and Duggan, S. (1995) Investigative work in the Science Curriculum. Buckingham, Open University Press.

Guariento, W. A. (1997). Innovation Management Issues Raised by Distance-Learning Project in Eritrea: Can Such Projects Be Successfully Transplanted from One Developing Country to Another? System, 25, 399-407.

Harlen, W. (2000) Teaching Learning and Assessing Science, pp. 80-89. London, Paul 
Chapman Publishing Ltd.

Hewson, P.W., Butler, J.K., Scantlebury, K.,. \& Davies, D. (2001). Equitable science education in urban middle schools: Do reform efforts make a difference? Journal of Research in Science Teaching, 38,1130-1144.

Hiebert, J. Gallimore, R \& Stigler, J. (2002) A knowledge base for the teaching profession: what would it look like and how can we get one? Education Researcher 31(5) 3-15.

Hoban, G.F. (2002) Teacher Learning for Educational Change. Buckingham, Open University Poress.

Huberman, M. and Miles, M. (1984) Innovation Up Close. New York, Plenum.

Johnson, S., Monk, M. and Hodges, M. (2000). Teacher Development and Change in South Africa: a critique of the appropriateness of transfer of northern/western practice. Compare, 30, 179-192.

Joyce, B \& Showers, B. (1988). Evaluating staff development programmes. In Student achievement through staff development chapt.9, pp.111-128. London: Longman.

Ladson-Billings, G. (1994). The dream keepers: successful teachers of African American Children:San Francisco:Jossey-Bass.

Lemke, J.L. (2001). Articulating Comunities: Sociocultural Perspectives on Science Education. Journal of Research in Science Teaching, 38, 296-316.

Lock, R. (1990) Open-ended problem-solving investigations: What do we mean and how can we use them? School Science Review 71(256) 63- 72.

Loucks-Horsley, S., Love, N., Stiles, K, Mundry, S. \& Hewson, P. (1998) Designing Professional Development for Teachers of Science and Mathematics. Thousand Oaks, 
CA, Corwin Press Inc.

Marx, R.W., Freeman, J.K., Krajick, J..S. \& Blumenfeld, P.C. (1998) Professional development of science teachers. In B.J. Fraser\& K.G. Tobin (Eds.), International handbook of teacher education. Dordrecht, Kluwer Academic Publishers.

Millar, R., Lubben, F., Gott, R. and Duggan, S. (1994) Investigating the school science laboratory: conceptual and procedural knowledge and their influence on performance. Research Papers in Education, 9, 207-248.

Monk, M., Johnson, S. \& Swain, J. (1998). Modelling Adaptation in the Evolution of an in-service programme: blind variation and selective retention in school-based observation activities. Journal of In-service Education, 24, 429-444.

Munby, H., Cunningham, M \& Lock, C. (2000). School science culture: A case-study of barriers to developing professional knowledge. Science Education, 84, 193-211.

National Board for Professional Teaching Standards (1998) Early Adolescence/Science Standards. Arlington, VA.

Peers, C.E., Diezmann, C.M. and Walters, J.J. (2003) Supports and Concerns for teacher ProfessionalGrowth During the Implementation of a Sciene Curriculum Innovation. Research in Science Education 33, 89-110.

Placier, P. and Hamilton, M.L. (1994) Schools as a context: a complex relationship in V. Richardso (ed.) A Theory of teacher change and the Process of Staff Development: A Case of Reading Instruction. New York, Teachers' College Press.

Putnam, R. T.; Borko, H. (2000) What Do New Views of Knowledge and Thinking Have to Say About Research on Teacher Learning? Educational Researcher 29(1) 4-16.

Ruiz-Primo, M.A. and Shavelson, R. (1995) Rhetoric and Reality in Science Performance URL: http://mc.manuscriptcentral.com/33 sed Email: editor_ijse@hotmail.co.uk 
Assessment: an Update. Paper presented at American Educational Research Association, San Francisco.

Sang, D. and Wood-Robinson, V. (2002) (Eds.) Teaching Secondary Scientific Enquiry. London, John Murray.

Scholtz, Z., Watson, R. and Amosun, O. (2004) Investigating science teachers response to curriculum development, African Journal of Research in Mathematics, Science and Technology Education, 8 (1): 41-52

Sebatane, E. M. (1994). Enhancement of teacher capacities and capabilities in schoolbased Assessment: Lesotho experience. Assessment in Education, 1, 223-224.

Showers, B., Joyce, B and Bennett, B (1987) Synthesis of research on staff development: a framework for future study and a state-of-the-art analysis Educational Leadership pp.77-87.

Soudien, C. \& Colyn, W. (1992). The Safety of Theory: Working with Educators in a Squatter Community. Journal of Educational Thought, 26, 258-71.

Stein, M.K., Smith, M. \& Silver, E.A. (1999). The development of professional developers: Learning to assist teachers in new settings in new ways. Harvard Educational Review, 69, 237-269.

Swain, J.R.L. (1991) The nature and assessment of scientific explorations in the classroom School Science Review 72(260) 65-77.

Taylor, R.M.(1990) The National Curriculum: a study to compare levels of attainment with data from the APU science surveys School Science Review 72(258) 31-37.

van Driel, J.H., Beijaard, D. and Verloop, N. (2001) Professional development and reform in science education: The role of teachers' practical knowledge Journal of 
Research in Science Teaching 38(2) 137-158.

Watson, J. R., Wood-Robinson, V. and Goldsworthy, A. (2000) Investigations: Targeted learning. Hatfield, Association for Science Education.

Watson, J.R. (2006) Beyond fair testing: Teaching different types of scientific enquiry. London, Gatsby Science Enhancement Programme.

Watson, J.R., Swain, J.R.L. and McRobbie, C. (1999) The interaction between teaching styles and pupil autonomy in practical science investigations: a case-study, pp. 148 159 in (eds.) Leach, J. and Paulsen, A. Practical Work in Science Education: Recent Research Studies. Roskilde University Press. ISBN 87-7867-079-9.

Watson, J.R., Wood-Robinson, V. and Goldsworthy, A. (1999) What is not fair about investigations School Science Review 80(292) 101-106.

Watson, R. and Wood-Robinson, V. (1998) Learning to Investigate pp.84-91 in (ed.) Ratcliffe, M. The ASE Guide to Secondary Science Education Cheltenham, Stanley Thornes.

Watson, R., Goldsworthy, A. and Wood-Robinson, V. (2002) What is not fair with investigations? pp. 53-59 in (eds.) Amos, S. and Boohan, R. Aspects of Secondary Science Teaching. London, Routledge Falmer

Wu, J. (1998). School Work Environment and Its Impact on the Professional Competence of Newly Qualified Teachers. Journal of In-service Education 24, 212-225. 
Table 1 Profiles of teachers taking part in the inquiry CPD

\begin{tabular}{|c|c|c|c|c|}
\hline Teacher & Summary of change & $\begin{array}{l}\text { Biographical } \\
\text { details }\end{array}$ & School details & $\begin{array}{l}\text { Participation in } \\
\text { the } \mathrm{CPD}\end{array}$ \\
\hline Fahima & $\begin{array}{l}\text { Fahima introduced more openness to } \\
\text { her inquiry work allowing more } \\
\text { pupil discussion, was more aware of } \\
\text { what constituted good quality } \\
\text { discussion in inquiry and was trying } \\
\text { to get the students to be more } \\
\text { reflective in their answers. She } \\
\text { extended the range of inquiries to } \\
\text { include a wider variety and was } \\
\text { beginning to use strategies for the } \\
\text { explicit teaching of procedural } \\
\text { understanding. }\end{array}$ & $\begin{array}{l}\text { Experienced } \\
\text { teacher. } \\
\text { No position of } \\
\text { responsibility. } \\
\text { Keen to learn. }\end{array}$ & $\begin{array}{l}\text { Suburban school - } \\
\text { mixed gender, } \\
\text { ethnicity and social } \\
\text { class. } \\
\text { School support for } \\
\text { CPD, expectation } \\
\text { that teachers } \\
\text { feedback. }\end{array}$ & $\begin{array}{l}\text { Attended 4/5 } \\
\text { workshops. } \\
\text { Completed all } \\
\text { in-school tasks } \\
\text { Completed a } \\
\text { portfolio. }\end{array}$ \\
\hline Charles & $\begin{array}{l}\text { Charles' portfolio showed that he } \\
\text { had learnt and used new pedagogical } \\
\text { approaches for teaching specific } \\
\text { aspects of inquiry. His interview } \\
\text { showed that he had moved away } \\
\text { from a position where he only taught } \\
\text { using whole inquiries, to thinking of } \\
\text { inquiry lessons in terms of specific } \\
\text { and limited objectives. The portfolio } \\
\text { also included a more extended range }\end{array}$ & $\begin{array}{l}\text { Novice teacher } \\
\text { No position of } \\
\text { responsibility. } \\
\text { Keen to learn. }\end{array}$ & $\begin{array}{l}\text { Private boys' } \\
\text { school. } \\
\text { Very strong support } \\
\text { in department for } \\
\text { CPD. Culture of } \\
\text { sharing of practice. }\end{array}$ & $\begin{array}{l}\text { Attended 4/5 } \\
\text { workshops. } \\
\text { Completed all } \\
\text { in-school } \\
\text { tasks. } \\
\text { Completed a } \\
\text { portfolio. }\end{array}$ \\
\hline
\end{tabular}




\begin{tabular}{|c|c|c|c|c|}
\hline & $\begin{array}{l}\text { of kinds of inquiry that he used in } \\
\text { his lessons. A video-tape that he } \\
\text { produced showed that he had } \\
\text { changed his questioning style to } \\
\text { emphasise explanation more. }\end{array}$ & & & \\
\hline Helen & $\begin{array}{l}\text { Helen saw the professional } \\
\text { development programme as } \\
\text { providing insight and strategies that } \\
\text { she could use to help her develop her } \\
\text { department. Her portfolio illustrated } \\
\text { a variety of ways in which she used } \\
\text { explicit teaching of aspects of } \\
\text { inquiry. She believed it was } \\
\text { important to have clear and limited } \\
\text { objectives for each inquiry lesson. } \\
\text { In spite of an advanced starting } \\
\text { position, she felt that the CPD } \\
\text { programme had been very valuable, } \\
\text { particularly time to reflect on her } \\
\text { own teaching. }\end{array}$ & $\begin{array}{l}\text { Experienced } \\
\text { teacher. } \\
\text { Head of } \\
\text { Science. } \\
\text { How to improve } \\
\text { dept. } \\
\text { Keen to learn } \\
\text { and motivate } \\
\text { her staff. }\end{array}$ & $\begin{array}{l}\text { Mixed } \\
\text { comprehensive in } \\
\text { small town. } \\
\text { Strong culture of } \\
\text { sharing of CPD in } \\
\text { the department. }\end{array}$ & $\begin{array}{l}\text { Attended 4/4 } \\
\text { workshops. } \\
\text { Completed all } \\
\text { in-school } \\
\text { tasks. } \\
\text { Completed a } \\
\text { portfolio. }\end{array}$ \\
\hline Priti & $\begin{array}{l}\text { Priti had a good knowledge of skills } \\
\text { and processes used in inquiry. } \\
\text { During the project she developed a } \\
\text { wider range of strategies for } \\
\text { teaching inquiry and a greater } \\
\text { variety of different inquiries, } \\
\text { including more those which were } \\
\text { more open. She became aware of }\end{array}$ & $\begin{array}{l}\text { Few years } \\
\text { experience. } \\
\text { No position of } \\
\text { responsibility. } \\
\text { Keen to learn. }\end{array}$ & $\begin{array}{l}\text { Mixed } \\
\text { comprehensive in } \\
\text { mixed social class } \\
\text { area. } \\
\text { Strong culture of } \\
\text { sharing of CPD in } \\
\text { the department. }\end{array}$ & $\begin{array}{l}\text { Attended 3/4 } \\
\text { workshops. } \\
\text { Completed all } \\
\text { in-school } \\
\text { tasks. } \\
\text { Completed a } \\
\text { portfolio. }\end{array}$ \\
\hline
\end{tabular}




\begin{tabular}{|c|c|c|c|c|}
\hline & collaborative aspects of inquiry. & & & \\
\hline Liz & $\begin{array}{l}\text { Through the professional } \\
\text { development programme Liz started } \\
\text { to teach specific aspects of } \\
\text { procedural understanding and } \\
\text { widened the variety of inquiries that } \\
\text { she used. She felt that she had } \\
\text { improved her ability to reflect } \\
\text { critically about her own practice. } \\
\text { She had also realised that her present } \\
\text { practice in inquiry lessons was very } \\
\text { teacher-directed and was trying to } \\
\text { hand over more control to students. }\end{array}$ & $\begin{array}{l}\text { Experienced } \\
\text { teacher. } \\
\text { No position of } \\
\text { responsibility }\end{array}$ & $\begin{array}{l}\text { Mixed gender } \\
\text { comprehensive in } \\
\text { mixed social class } \\
\text { area. } \\
\text { Good relations in } \\
\text { science department } \\
\text { but no mechanism } \\
\text { for sharing of } \\
\text { practice or CPD. }\end{array}$ & $\begin{array}{l}\text { Attended 5/5 } \\
\text { workshops. } \\
\text { Some in- } \\
\text { school tasks } \\
\text { done. } \\
\text { No portfolio as } \\
\text { she thought it } \\
\text { was } \\
\text { 'incomplete'. }\end{array}$ \\
\hline Jack & $\begin{array}{l}\text { Jack became more aware of the role } \\
\text { of discussion and collaboration in } \\
\text { inquiry, but demonstrated no other } \\
\text { changes in his knowledge and } \\
\text { understanding or teaching of inquiry. }\end{array}$ & $\begin{array}{l}\text { Experienced } \\
\text { teacher. } \\
\text { Head of } \\
\text { Department }\end{array}$ & $\begin{array}{l}\text { Urban girls' } \\
\text { comprehensive. } \\
\text { No evidence of } \\
\text { sharing practice } \\
\text { within science } \\
\text { department. }\end{array}$ & $\begin{array}{l}\text { Attended } 3 / 4 \\
\text { workshops } \\
\text { Completed } \\
\text { most tasks. } \\
\text { Did not present } \\
\text { a portfolio }\end{array}$ \\
\hline Mary & $\begin{array}{l}\text { Mary developed her knowledge and } \\
\text { understanding of the skills and } \\
\text { processes of inquiry. She was aware } \\
\text { of a range of strategies for teaching } \\
\text { inquiry, but without recognising the } \\
\text { need for explicit objectives. }\end{array}$ & $\begin{array}{l}\text { Experienced } \\
\text { teacher, second } \\
\text { in department. }\end{array}$ & $\begin{array}{l}\text { Suburban } \\
\text { comprehensive } \\
\text { school in working } \\
\text { class area. }\end{array}$ & $\begin{array}{l}\text { Attended 2/4 } \\
\text { workshops. } \\
\text { Did not present } \\
\text { a portfolio. }\end{array}$ \\
\hline Pamela & $\begin{array}{l}\text { Expressed a view that she already } \\
\text { had good knowledge of teaching } \\
\text { inquiry. }\end{array}$ & $\begin{array}{l}\text { Experienced } \\
\text { teacher. }\end{array}$ & $\begin{array}{l}\text { Inner city girls' } \\
\text { school. }\end{array}$ & $\begin{array}{l}\text { Limited } \\
\text { engagement in } \\
\text { CPD. }\end{array}$ \\
\hline
\end{tabular}




\begin{tabular}{|c|c|c|c|c|}
\hline Milton & $\begin{array}{l}\text { Maybe raised awareness, but limited } \\
\text { evidence of change. }\end{array}$ & $\begin{array}{l}\text { New teacher, } \\
\text { limited } \\
\text { experience. }\end{array}$ & $\begin{array}{l}\text { Mixed gender } \\
\text { suburban } \\
\text { comprehensive. } \\
\text { CPD low priority in } \\
\text { the school, no } \\
\text { encouragement to } \\
\text { attend or feedback } \\
\text { to colleagues. }\end{array}$ & $\begin{array}{l}\text { Attended } 2 / 5 \\
\text { workshops. } \\
\text { No tasks or } \\
\text { portfolios } \\
\text { completed. }\end{array}$ \\
\hline Mila & $\begin{array}{l}\text { Mila tended to view her practice as } \\
\text { exemplary but did not appear to have } \\
\text { a good grasp of the criteria by which } \\
\text { practice in this field could be } \\
\text { evaluated. She claimed to be } \\
\text { teaching aspects of inquiry through } \\
\text { explicit teaching during normal } \\
\text { theory lessons but it was not clear } \\
\text { exactly what was being taught. She } \\
\text { did, however, include a greater } \\
\text { variety of inquiries in her lessons. }\end{array}$ & $\begin{array}{l}\text { Experienced } \\
\text { teacher. No } \\
\text { position of } \\
\text { responsibility. }\end{array}$ & $\begin{array}{l}\text { Mixed gender } \\
\text { urban } \\
\text { comprehensive. } \\
\text { CPD had low } \\
\text { priority within the } \\
\text { school. }\end{array}$ & $\begin{array}{l}\text { Attended } 3 / 5 \\
\text { sessions. } \\
\text { Completed one } \\
\text { in-school task. } \\
\text { No portfolio } \\
\text { presented. }\end{array}$ \\
\hline
\end{tabular}

